\title{
A Comparative Study to Assess the Effectiveness of Turmeric Mouth Wash versus Saline Mouth Wash on Treatment Induced Oral Mucositis (Tiom) in a Selected Hospital at Mangalore
}

\author{
Steven Peter Saldanha ${ }^{1}$ and Victoria D Almeida ${ }^{2^{*}}$ \\ ${ }^{1}$ Medical Surgical Nursing PG Graduate, Father Muller College of Nursing, Mangalore, India \\ ${ }^{2}$ Medical Surgical Nursing, Vice Principal, Father Muller College of Nursing, Mangalore, India \\ ${ }^{*}$ Corresponding author: Victoria D Almeida, Professor, Medical Surgical Nursing, Vice Principal, Father Muller College of Nursing, Mangalore, India, Tel: 09880305653; \\ Email: victoriacornelio@yahoo.com
}

Rec date: Jun 02, 2014, Acc date: Nov 10, 2014, Pub date: Nov 15, 2014

Copyright: (c) 2014 Saldanha SP, et al. This is an open-access article distributed under the terms of the Creative Commons Attribution License, which permits unrestricted use, distribution, and reproduction in any medium, provided the original author and source are credited.

\begin{abstract}
Oral mucositis is the most common, debilitating complication of cancer treatments. Chemotherapy and/or radiation therapy will interfere with the normal turnover of epithelial, cells leading to mucosal injury. The care of these patients includes the regular use of an effective mouth wash periodically. The active ingredient in turmeric is curcumin which protects healthy cells from harmful effects of radiation and chemotherapy. Salt mouthwash can soothe the pain and keep food particles clear so as to avoid infection. The study made use of a two group pre-test post-test time series design to determine the effectiveness of Turmeric and Saline mouth wash on TIOM. A purposive random sampling was used and mouth wash was given three times daily for 5 days. The oral mucosa of the patients was assessed using an Oral Mucositis assessment checklist and pain using pain scale every morning before the intervention and evening after the intervention. There was a significant difference in the score of TIOM between pre-intervention on Day 1 morning and post intervention score on day 5 evening in turmeric and saline group but on comparison it was found that turmeric mouth wash was effective than saline mouth in all the days except in Day 3 where there was no significant difference found. Both the mouth wash were individually effective but on comparison turmeric mouth wash was better than saline mouth wash.
\end{abstract}

Keywords: Effectiveness; Turmeric; Normal saline; Oral mucositis; Mouth wash; Salt

\section{Introduction}

Mucositis is the painful inflammation and ulceration of the mucous membrane, usually as an adverse effect of chemotherapy and radiotherapy treatment for cancer. Chemotherapy-induced oral mucositis causes the mucosal lining of the mouth to atrophy and break down forming ulcers and affects almost all patients undergoing highdose chemotherapy. Radiotherapy to the head and neck or to the pelvis or abdomen is associated with the occurrence of oral mucositis, often exceeding $50 \%$ of patients. Among patients undergoing head and neck radiotherapy, pain and decreased oral function may persist long after the conclusion of therapy. Fractionated radiation dosage increases the risk of mucositis to $>70 \%$ of patients in most trials [1-20].

A study was conducted in the department of Dental Medicine, Winthrop university hospital New York, and it stated that, the oral mucosa is a common site for collateral damage of cancer therapies, including radiation, cytotoxic medication, and newer targeted therapies. Ulcerative oral mucositis is typically painful and affects oral functions including speech, and oral intake of food and medications, thus impacting the quality of life. Prevention of oral mucositis is an ongoing quest currently with relatively few answers. Oral mucositis not only has a dramatic impact on the patient's quality of life, but it also can adversely influence the administration of an optimal antineoplasic treatment.
Turmeric is one of nature's most powerful healers. Turmeric has been used for over 2500 years in India. Research conducted at the University of Michigan, by Ayyalusamy Ramamurthy in 2009, showed that curcumin in turmeric helps regulate cells by inserting itself into the cell membranes and interfering with molecular pathways that lead to cancer development and spread. This causes the cells to become less susceptible to infection and even to cancer. Salt mouthwash can soothe the pain and keep food particles clear so as to avoid infection [3]. Normal saline $(0.9 \%)$ is a not irritant and is believed to help in formation of granulation tissue and to promote healing. It's safe, economical and readily available mouthwash. Salt water mouthwash rinses are considered an excellent treatment when we have wounds in the mouth. The reason is that salt water is not only a natural disinfectant but it also removes any swelling from the tissue. Giving a mouth wash to the patients with a medicinal property like those of turmeric or normal saline can prove very economical and beneficial for the patient in terms of cure and relieve from symptoms and also in regards to its use in the future and preventing complications [21-28].

\section{Materials and Methods}

Prior permission was obtained from the ethical committee of the Institutional Research Board (IRB). In order to accomplish the main objectives of determining the effectiveness of turmeric or saline mouth wash on treatment induced oral mucositis among patients with cancer undergoing treatment an evaluative research approach was adopted. The research design used in this study was Repeated Measures two group Pre-test Post-test time series design. This study was conducted at Father Muller Medical College Hospital, which is a super speciality 
Citation: Saldanha SP, Almeida VD (2014) A Comparative Study to Assess the Effectiveness of Turmeric Mouth Wash versus Saline Mouth Wash on Treatment Induced Oral Mucositis (Tiom) in a Selected Hospital at Mangalore. J Clinic Res Bioeth 5: 200. doi: $10.4172 / 2155-9627.1000200$

Page 2 of 5

hospital with 1250 beds with 100 beds for oncology patients. The present study was conducted in oncology wards of this hospital. A purposive sampling technique was used. The subjects for this study consisted of 40 patients, 20 in experimental group I receiving Turmeric mouth wash (Mouth wash solution prepared by mixing 1.5 gms of turmeric powder with $50 \mathrm{ml}$ of water. Each time a $50 \mathrm{ml}$ of freshly prepared turmeric mouth wash solution will be administered) and 20 in Group II receiving saline mouth wash (It refers to $0.9 \mathrm{gm}$ of salt in $100 \mathrm{ml}$ of water which contains sodium $150 \mathrm{mmol} / \mathrm{litre}$ and chloride $150 \mathrm{mmol} /$ litre. It is a readily available normal saline concentration which is available for IV therapy in hospital use). In this study baseline proforma was used to collect the baseline data from the sample. A self-prepared tool for assessing the oral mucositis among cancer patient was developed according to their clinical signs and symptoms for gathering maximum data and according to the scores the patient was classified from Grade I to Grade IV. The level of pain in the patient was assessed using a standardized pain rating scale according to which the pain was classified as mild, moderate and severe. The tools were send for validation to the experts and the necessary corrections were made. Inter rater reliability was used to find out the reliability of the tool. The correlation was computed using the inter-class correlation co-efficient. The inter rater reliability was found to be 0.89 which indicated the tool was reliable [29-33].

\section{Results}

The data was tabulated, analyzed and interpreted using the descriptive and inferential statistics. The data was analyzed using SPSS $16^{\text {th }}$ version.

The mean pre-test TIOM score of group I is $\mathrm{X}_{1}=25.35$ whereas in post-test it is $\mathrm{X}_{2}=18.85$. The mean of pre-test TIOM score of group II is $X_{1}=25.05$ whereas in post-test it is $X_{2}=20.15$. The standard deviation of pretest TIOM score of group I and group II in pretest is 4.97 and 6.62 respectively whereas the standard deviation of post-test TIOM score of group I and group II is 4.23 and 5.86 respectively. The mean post-interventional scores in group I (post $\mathrm{Day}_{5}=18.85$ ), (post Day $_{4}=20$ ), (post $\mathrm{D}_{3}=21.50$ ), (post $\mathrm{D}_{2}=22.75$ ), (post $\mathrm{D}_{1}=24.15$ )of TIOM is significantly lower than the mean pre-interventional scores (pre Day $\left._{1}=25.35\right)$. The computed value of $F(5,95)=268.05$ is significantly greater than the tabled value $\mathrm{F}(5,95)=2.31$ which shows that Turmeric mouth wash is effective on the grade of TIOM. The mean postinterventional scores in group II (post Day $_{5}=20.15$ ), (post Day $_{4}=21.10$ ), (post $\mathrm{D}_{3}=21.80$ ), (post $\mathrm{D}_{2}=23.25$ ), (post $\mathrm{D}_{1}=24.30$ ) of TIOM is significantly lower than the mean pre-interventional scores (pre $\mathrm{Day}_{1}=25.05$ ). The computed value of $\mathrm{F}(5,95)=144.06$ is significantly greater than the tabled value $F(5,95)=2.31$ which shows that Saline mouth wash is effective on the grade of TIOM (Tables 1-8).

\begin{tabular}{|l|l|l|l|l|}
\hline & \multicolumn{2}{|l|}{ Group I (Turmeric) } & \multicolumn{2}{l|}{ Group II (Saline) } \\
\hline Variables & Frequency & $\begin{array}{l}\text { Percentag } \\
\text { e (\%) }\end{array}$ & Frequency & $\begin{array}{l}\text { Percenta } \\
\text { ge (\%) }\end{array}$ \\
\hline 1.Age in Years & & & \\
\hline b.31-50 & 6 & 30 & 10 & 50 \\
\hline c.51-75 & 14 & 70 & 10 & 50 \\
\hline 2.Gender & 16 & 80 & 16 & 80 \\
\hline a. Male & 16 & & & \\
\hline
\end{tabular}

\begin{tabular}{|c|c|c|c|c|}
\hline b. Female & 4 & 20 & 4 & 20 \\
\hline \multicolumn{5}{|c|}{ 3.Diagnosis on Admission } \\
\hline a. Ca head and Neck & 18 & 90 & 16 & 80 \\
\hline b. Others & 2 & 10 & 4 & 20 \\
\hline \multicolumn{5}{|c|}{ 4.Any Associated Disease } \\
\hline a. Yes & 0 & 0 & 3 & 15 \\
\hline b. No & 20 & 100 & 17 & 85 \\
\hline \multicolumn{5}{|l|}{ 5.Treatment Modality } \\
\hline a. Chemotherapy & 1 & 5 & 3 & 15 \\
\hline b. Radiation therapy & 3 & 15 & 1 & 5 \\
\hline $\begin{array}{l}\text { c. Chemotherapy and } \\
\text { Radiation therapy }\end{array}$ & 16 & 80 & 16 & 80 \\
\hline
\end{tabular}

Table 1: Frequency and Percentage Distribution of Subjects According to their Baseline Characteristics.

\begin{tabular}{|c|c|c|c|c|c|c|c|c|}
\hline & \multicolumn{2}{|c|}{$\begin{array}{l}\text { Group } \\
\text { I(Turmeric) }\end{array}$} & \multirow[b]{2}{*}{ Post test } & & \multicolumn{2}{|c|}{$\begin{array}{l}\text { Group } \\
\text { II(Saline) }\end{array}$} & \multirow[b]{2}{*}{$\begin{array}{l}\text { Post } \\
\text { test }\end{array}$} & \\
\hline & $\begin{array}{l}\text { Pre } \\
\text { test }\end{array}$ & & & & $\begin{array}{l}\text { Pre } \\
\text { test }\end{array}$ & & & \\
\hline TIOM & $f$ & $\%$ & $f$ & $\%$ & $f$ & $\%$ & $f$ & $\%$ \\
\hline \multicolumn{9}{|l|}{ Score } \\
\hline $11-15$ & 2 & 10 & 4 & 20 & 2 & 10 & 5 & 25 \\
\hline $16-20$ & 2 & 10 & 12 & 60 & 2 & 10 & 4 & 20 \\
\hline $21-25$ & 4 & 20 & 3 & 15 & 4 & 20 & 9 & 45 \\
\hline $26-30$ & 10 & 50 & 1 & 5 & 10 & 50 & 2 & 10 \\
\hline $31-35$ & 2 & 10 & 0 & 0 & 2 & 10 & 0 & 0 \\
\hline
\end{tabular}

Table 2: Distribution of Subjects According to the TIOM Scores Obtained in Group I and Group II.

\begin{tabular}{|l|l|l|l|l|l|l|l|l|l|}
\hline \multicolumn{2}{|l|}{} & \multicolumn{3}{|l|}{ Group I(Turmeric) } & \multicolumn{3}{l|}{ Group II(Saline) } \\
\hline \multicolumn{2}{|l|}{} & \multicolumn{2}{|l|}{ Pre test } & \multicolumn{2}{l|}{ Post test } & \multicolumn{2}{l|}{ Pre test } & \multicolumn{2}{l|}{ Post test } \\
\hline $\begin{array}{l}\text { IIOM } \\
\text { Scores }\end{array}$ & Grades & f & $\%$ & f & $\%$ & f & $\%$ & f & $\%$ \\
\hline $15-J a n$ & Grade I & 2 & 10 & 4 & 20 & 4 & 20 & 5 & 25 \\
\hline $16-30$ & Grade II & 15 & 75 & 16 & 80 & 13 & 65 & 15 & 75 \\
\hline $31-45$ & Grade III & 3 & 15 & 0 & 0 & 3 & 15 & 0 & 0 \\
\hline
\end{tabular}

Table 3: Distribution of Subjects According to the Grade of TIOM in Group I and Group II.

\begin{tabular}{|l|l|l|l|l|l|l|}
\hline & \multicolumn{2}{|l|}{ Range } & \multicolumn{2}{l|}{ Mean } & \multicolumn{2}{l|}{$\begin{array}{l}\text { Standard } \\
\text { Deviation }\end{array}$} \\
\hline Groups & $\begin{array}{l}\text { Pre } \\
\text { test }\end{array}$ & $\begin{array}{l}\text { Post } \\
\text { test }\end{array}$ & Pre test & Post test & Pre test & $\begin{array}{l}\text { Post } \\
\text { test }\end{array}$ \\
\hline
\end{tabular}


Citation: Saldanha SP, Almeida VD (2014) A Comparative Study to Assess the Effectiveness of Turmeric Mouth Wash versus Saline Mouth Wash on Treatment Induced Oral Mucositis (Tiom) in a Selected Hospital at Mangalore. J Clinic Res Bioeth 5: 200. doi: $10.4172 / 2155-9627.1000200$

Page 3 of 5

\begin{tabular}{|l|l|l|l|l|l|l|}
\hline Group I & 19 & 16 & 25.35 & 18.85 & 4.97 & 4.23 \\
\hline Group II & 21 & 19 & 25.05 & 20.15 & 6.62 & 5.86 \\
\hline
\end{tabular}

Table 4: Range, Mean and Standard Deviation of pre-test and post-test TIOM Score.

\begin{tabular}{|l|l|l|l|l|l|l|}
\hline Group & $\begin{array}{l}\text { Minimum } \\
\text { Score }\end{array}$ & $\begin{array}{l}\text { Maximu } \\
\text { m Score }\end{array}$ & Mean & $\begin{array}{l}\text { Standa } \\
\text { rd } \\
\text { deviati } \\
\text { on }\end{array}$ & t-value & p-value \\
\hline Turmeric & 14 & 33 & 25.35 & 4.97 & 0.16 & 0.87 \\
\hline $\begin{array}{l}\text { Normal } \\
\text { saline }\end{array}$ & 13 & 34 & 25.05 & 6.62 & & \\
\hline$t(38)=2.02, p<0.05$ & & & & & \\
\hline
\end{tabular}

Table 5: Significant difference between the Pre-interventional TIOM score in Group I and Group II.

\begin{tabular}{|l|l|l|l|l|}
\hline Day & Mean & $\begin{array}{l}\text { Standard } \\
\text { Deviation }\end{array}$ & $\begin{array}{l}\text { Anova } \\
\text { value }\end{array}$ & p-value \\
\hline Pre $D_{1}$ & 25.35 & 4.97 & $268.05^{*}$ & $p<0.001$ \\
\hline Post $D_{1}$ & 24.15 & 4.68 & & \\
\hline Post $D_{2}$ & 22.75 & 4.71 & & \\
\hline Post $D_{3}$ & 21.5 & 4.36 & & \\
\hline Post $D_{4}$ & 20 & 4.46 & & \\
\hline Post $D_{5}$ & 18.85 & 4.23 & & \\
\hline$F(5,95)=2.31, p<0.05,{ }^{*}=$ significant & \\
\hline
\end{tabular}

Table 6: Effectiveness of Turmeric Mouth Wash on the Grade of TIOM on Day 1 Morning and Day 1 to Day 5 Evening.

\begin{tabular}{|c|c|c|c|c|}
\hline \multicolumn{5}{|c|}{ Turmeric group(Group I) } \\
\hline Day & $\begin{array}{l}\text { Mean } \\
\text { Differenc } \\
\text { e }\end{array}$ & $\begin{array}{l}\text { Standard } \\
\text { Deviatio } \\
\text { n } \\
\text { Differenc } \\
\text { e }\end{array}$ & t-value & p-value \\
\hline Post $D_{1}$-Post $D_{2}$ & 1.4 & 0.75 & $8.30^{*}$ & $p<0.001$ \\
\hline Post $D_{1}$-Post $D_{3}$ & 2.65 & 0.93 & $12.70^{*}$ & $p<0.001$ \\
\hline Post $D_{1}$ - Post $D_{4}$ & 4.15 & 0.93 & $19.89^{*}$ & $p<0.001$ \\
\hline Post $D_{1}$ - Post $D_{5}$ & 5.3 & 1.08 & $21.93^{*}$ & $p<0.001$ \\
\hline Post $D_{2}-$ Post $D_{3}$ & 1.25 & 0.55 & $10.16^{*}$ & $p<0.001$ \\
\hline Post $D_{2}$ - Post $D_{4}$ & 2.75 & 0.71 & $17.17^{*}$ & $p<0.001$ \\
\hline Post $D_{2}$-Post $D_{5}$ & 3.9 & 0.97 & $18.02^{*}$ & $\mathrm{p}<0.001$ \\
\hline Post $D_{3}-$ Post $D_{4}$ & 1.5 & 0.61 & $11.05^{*}$ & $p<0.001$ \\
\hline Post $D_{3}$ - Post $D_{5}$ & 2.65 & 0.81 & $14.58^{*}$ & $p<0.001$ \\
\hline
\end{tabular}

\begin{tabular}{|l|l|l|l|l|}
\hline Post $\mathrm{D}_{4}$ - Post $\mathrm{D}_{5}$ & 1.15 & 0.67 & $7.67^{*}$ & $\mathrm{p}<0.001$ \\
\hline $\mathrm{t}_{19}=2.093, \mathrm{p}<0.05,{ }^{*}=$ significant \\
\hline
\end{tabular}

Table 7: Significant Difference in the Mean Post-interventional TIOM scores from Day 1 to Day 5 in group I.

\begin{tabular}{|l|l|l|l|l|l|}
\hline Day & Time of the day & Mean & 't' value & $\mathbf{p}$ value & Inference \\
\hline 1 & $\begin{array}{l}\text { Morning pre- } \\
\text { intervention }\end{array}$ & 25.35 & 20.31 & $p<0.001$ & Significant \\
\hline 5 & $\begin{array}{l}\text { Evening post- } \\
\text { intervention }\end{array}$ & 18.85 & & & \\
\hline
\end{tabular}

Table 8: Significant difference between the mean pre-interventional TIOM score on Day 1 and the mean post interventional TIOM score on Day 5.

\section{Discussion}

In the present study, majority of the subjects $18(90 \%)$ in group I and $16(80 \%)$ in group II had cancer of head and neck whereas $2(10 \%)$ in group I and $4(20 \%)$ in group II had cancer of other origin. The study findings are in accordance with the findings of a study conducted in USA to characterize the risks and clinical consequences of oral mucositis (OM) in patients with Head and Neck Carcinoma (HNC) which showed that primary tumor locations included the oropharynx $(26.4 \%)$, larynx $(26.4 \%)$, oral cavity including the lip (24.4\%), hypo pharynx (13.6\%), and nasopharynx (9.1\%). In the present study, turmeric mouth wash was given to 20 subjects in group I three times a day and pre and post assessment was done on all the 5 days of intervention it was found to be significantly effective on all the 5 days with the reduction in mean $\left(\mathrm{X}^{-}=25.35\right)$ on Day 1 to $\left(\mathrm{X}^{-}=18.85\right)$ post day 5 and the calculated $F$ value (268.05) was significantly greater than the tabled value (2.305) indicating its effectiveness at all time points. These findings are in accordance with the findings of an investigational study which was conducted to evaluate the efficacy of turmeric in preventing radiation induced oral mucositis in patients receiving head and neck cancer which showed that when compared with the cohorts using povidone-iodine gargle, the group using turmeric as a mouth wash had delayed and reduced the levels of radiation-induced oral mucositis and was statistically significant at all time points $(:<0.001$ to $:<0.0001)$. Additionally, the cohorts using turmeric had decreased intolerable mucositis $(:<0.001)$ and lesser incidence of treatment breaks in the first half of the treatment schedule before 4 weeks $(:<0.01)$ and reduced change in body weight $(:<0.001)$.Gargling with turmeric by head and neck cancer patients undergoing radiation therapy provided significant benefit by delaying and reducing the severity of mucositis. In the present study paired $t$ test was computed at a level of 0.05 significance between preintervention on day 1 and post-intervention day 5 and found that the calculated $t$ value $(t=17.81)$ was significantly greater than the tabled value $(t=2.093)$ indicating turmeric mouth wash is effective on TIOM. These findings were in accordance with the finding of a study conducted in the department of Dermatology at University of Rochester, USA where $t$ test showed that curcumin reduced RDS at end of treatment compared to placebo (mean $\mathrm{RDS}=2.6$ vs. 3.4; $\mathrm{P}=0.008$ ) (Tables 9-12). 
Citation: Saldanha SP, Almeida VD (2014) A Comparative Study to Assess the Effectiveness of Turmeric Mouth Wash versus Saline Mouth Wash on Treatment Induced Oral Mucositis (Tiom) in a Selected Hospital at Mangalore. J Clinic Res Bioeth 5: 200. doi:

Page 4 of 5

\begin{tabular}{|l|l|l|l|l|}
\hline Day & Mean & $\begin{array}{l}\text { Standard } \\
\text { Deviation }\end{array}$ & Anova F & p value \\
\hline Pre D1 & 25.05 & 6.62 & $144.06^{*}$ & $\mathrm{p}<0.001$ \\
\hline Post D1 & 24.3 & 6.36 & & \\
\hline Post D2 & 23.25 & 6.31 & & \\
\hline Post D3 & 21.8 & 6.21 & & \\
\hline Post D4 & 21.1 & 6.04 & & \\
\hline Post D5 & 20.15 & 5.86 & & \\
\hline F (5,95)=2.31, p>0.05, ${ }^{*}=$ significant & & \\
\hline
\end{tabular}

Table 9: Effectiveness of Saline Mouth Wash on the Grade of TIOM on Day 1 Morning and Day 1 to Day 5 Evening.

\begin{tabular}{|l|l|l|l|l|}
\hline \multicolumn{2}{|l|}{ Saline group (Group II ) } & \multicolumn{5}{l|}{$\begin{array}{l}\text { Mean } \\
\text { differen } \\
\text { ce }\end{array}$} & $\begin{array}{l}\text { Standard } \\
\text { Deviation } \\
\text { Difference }\end{array}$ & 't' value & 'p' value \\
\hline Post D1- Post D2 & 1.05 & 1.05 & $4.47^{*}$ & $p<0.001$ \\
\hline Post D1- Post D3 & 2.5 & 1 & $11.18^{*}$ & $p<0.001$ \\
\hline Post D1- Post D4 & 3.2 & 1.056 & $13.55^{*}$ & $p<0.001$ \\
\hline Post D1- Post D5 & 4.15 & 1.186 & $15.70^{*}$ & $p<0.001$ \\
\hline Post D2- Post D3 & 1.45 & 0.686 & $9.45^{*}$ & $p<0.001$ \\
\hline Post D2- Post D4 & 2.15 & 0.875 & $10.99^{*}$ & $p<0.001$ \\
\hline Post D2- Post D5 & 3.1 & 0.912 & $15.20^{*}$ & $p<0.001$ \\
\hline Post D3- Post D4 & 0.7 & 0.571 & $5.48^{*}$ & $p<0.001$ \\
\hline Post D3- Post D5 & 1.65 & 0.671 & $11.00^{*}$ & $p<0.001$ \\
\hline Post D4- Post D5 & 0.95 & 0.394 & $10.78^{*}$ & $p<0.001$ \\
\hline t 19=2.093, p>0.05, * =significant & & & \\
\hline
\end{tabular}

Table 10: Significant Difference in the Mean Post-interventional TIOM scores from Day 1 to Day 5 in group II.

\begin{tabular}{|l|l|l|l|l|l|}
\hline Day & Time of the day & Mean & 't' value & $p$-value & Inference \\
\hline 1 & Morning pre-intervention & 25.05 & 17.81 & $p<0.001$ & Significant \\
\hline 5 & Evening post-intervention & 20.15 & & & \\
\hline$t_{19}=2.093, p<0.05$
\end{tabular}

Table 11: Significant difference between the mean pre-intervention Day 1 TIOM score and the mean post intervention Day 5 TIOM score.

\begin{tabular}{|l|l|l|l|l|l|l|}
\hline Day & Group & $\begin{array}{l}\text { Mean } \\
\text { differenc } \\
\text { e }\end{array}$ & $\begin{array}{l}\text { Standard } \\
\text { Deviation } \\
\text { Difference }\end{array}$ & Mean \% & 't' value & $\begin{array}{l}\text { p- } \\
\text { value }\end{array}$ \\
\hline $\begin{array}{l}\text { Pre D1 } \\
\text {-post } \\
\text { D1 }\end{array}$ & Turmeric & 1.2 & 0.616 & 4.73 & $2.27^{\star}$ & 0.029 \\
\hline
\end{tabular}

\begin{tabular}{|c|c|c|c|c|c|c|}
\hline $\begin{array}{l}\text { Pre D1 } \\
\text {-post } \\
\text { D1 }\end{array}$ & $\begin{array}{l}\text { Normal } \\
\text { saline }\end{array}$ & 0.75 & 0.639 & 2.99 & & \\
\hline $\begin{array}{l}\text { Pre D1 } \\
\text {-post } \\
\text { D2 }\end{array}$ & Turmeric & 2.6 & 1.142 & 10.26 & \multirow[t]{2}{*}{$2.05^{*}$} & \multirow[t]{2}{*}{0.048} \\
\hline $\begin{array}{l}\text { Pre D1 } \\
\text {-post } \\
\text { D2 }\end{array}$ & $\begin{array}{l}\text { Normal } \\
\text { saline }\end{array}$ & 1.8 & 1.322 & 7.19 & & \\
\hline $\begin{array}{l}\text { Pre D1 } \\
\text {-post } \\
\text { D3 }\end{array}$ & Turmeric & 3.85 & 1.309 & 15.19 & \multirow[t]{2}{*}{1.46} & \multirow[t]{2}{*}{0.153} \\
\hline $\begin{array}{l}\text { Pre D1 } \\
\text {-post } \\
\text { D3 }\end{array}$ & $\begin{array}{l}\text { Normal } \\
\text { saline }\end{array}$ & 3.25 & 1.293 & 12.97 & & \\
\hline $\begin{array}{l}\text { Pre D1 } \\
\text {-post } \\
\text { D4 }\end{array}$ & Turmeric & 5.35 & 1.226 & 21.1 & \multirow[t]{2}{*}{$3.54^{*}$} & \multirow[t]{2}{*}{0.001} \\
\hline $\begin{array}{l}\text { Pre D1 } \\
\text {-post } \\
\text { D4 }\end{array}$ & $\begin{array}{l}\text { Normal } \\
\text { Saline }\end{array}$ & 3.95 & 1.276 & 15.77 & & \\
\hline $\begin{array}{l}\text { Pre D1 } \\
\text {-post } \\
\text { D5 }\end{array}$ & Turmeric & 6.5 & 1.433 & 25.64 & \multirow[t]{2}{*}{$3.51^{*}$} & \multirow[t]{2}{*}{0.001} \\
\hline $\begin{array}{l}\text { Pre D1 } \\
\text {-post } \\
\text { D5 }\end{array}$ & $\begin{array}{l}\text { Normal } \\
\text { saline }\end{array}$ & 4.9 & 1.447 & 19.56 & & \\
\hline
\end{tabular}

Table 12: Comparison of the Effectiveness of Turmeric Mouth Wash and Normal Saline Mouth Wash on the Grade of TIOM among the patient with cancer.

\section{Nursing Implications}

The curriculum of nursing can incorporate the planning, development and implementation of complimentary therapies so that the students become aware of these therapies and help the patients for their speedy recovery and prevent chances of life threatening complications.

\section{Recommendations}

Keeping in view the findings of the study the following recommendations were made:

The study can be replicated on a larger sample to have generalization.

A similar study can be conducted in different settings and results can be compared.

The effectiveness of turmeric mouth wash can be compared with other complimentary treatment modality.

A similar study could be done with a control group.

The effectiveness of turmeric or saline mouth wash could be compared with either Soda bicarbonate or Betadine mouth wash which is the protocol followed in most of the hospitals for treating TIOM. The effectiveness of turmeric could be found out on other oral conditions [34-45]. 
Citation: Saldanha SP, Almeida VD (2014) A Comparative Study to Assess the Effectiveness of Turmeric Mouth Wash versus Saline Mouth Wash on Treatment Induced Oral Mucositis (Tiom) in a Selected Hospital at Mangalore. J Clinic Res Bioeth 5: 200. doi: $10.4172 / 2155-9627.1000200$

Page 5 of 5

\section{Acknowledgement}

A special note of thanks to God Almighty, Professor Victoria D' Almeida(Vice Principal), Experts in the field, family and friends.

\section{References}

1. Naidu MU, Ramana GV, Rani PU, Mohan IK, Suman A, et al. (2004) Chemotherapy-induced and/or radiation therapy-induced oral mucositis--complicating the treatment of cancer. Neoplasia 6: 423-431.

2. Elting LS, Cooksley CD, Chambers MS, Garden AS (2007) Risk, outcomes, and costs of radiation-induced oral mucositis among patients with head-and-neck malignancies. Int J Radiat Oncol Biol Phys 68: 1110-1120.

3. Barasch A, Epstein JB (2011) Management of cancer therapy-induced oral mucositis. Dermatol Ther 24: 424-431.

4. Rajesh VL, Stephen TS, Douglas EP (2008) Management of oral mucositis in patients with cancer. Journal of Dental Clinic North America 52: 61.

5. Brown CG, Wingard J (2004) Clinical consequences of oral mucositis. Semin Oncol Nurs 20: 16-21.

6. Mali AM, Behal R, Gilda SS (2012) Comparative evaluation of $0.1 \%$ turmeric mouthwash with $0.2 \%$ chlorhexidine gluconate in prevention of plaque and gingivitis: A clinical and microbiological study. J Indian Soc Periodontol 16: 386-391.

7. Lüer S, Troller R, Aebi C (2012) Antibacterial and antiinflammatory kinetics of curcumin as a potential antimucositis agent in cancer patients. Nutr Cancer 64: 975-981.

8. Muglikar S, Patil KC, Shivswami S, Hegde R (2013) Efficacy of curcumin in the treatment of chronic gingivitis: a pilot study. Oral Health Prev Dent 11: 81-86.

9. Rajesh VL, Stephen TS, Douglas EP (2008) Management of oral mucositis in patients with cancer. Journal of Dental Clinic North America 52: 61.

10. Miller M, Kearney N (2001) Oral care for patients with cancer: a review of the literature. Cancer Nurs 24: 241-254.

11. Rodríguez-Caballero A, Torres-Lagares D, Robles-García M, PachónIbáñez J, González-Padilla D, et al. (2012) Cancer treatment-induced oral mucositis: a critical review. Int J Oral Maxillofac Surg 41: 225-238.

12. Wong PC, Dodd MJ, Miaskowski C, Paul SM, Bank KA, et al. (2006) Mucositis pain induced by radiation therapy: prevalence, severity, and use of self-care behaviors. J Pain Symptom Manage 32: 27-37.

13. Leung WK, Dassanayake RS, Yau JY, Jin LJ, Yam WC et al. (2000) Oral colonization, phenotypic and genotypic profiles of candida species in irradiated, dentate, xerostomic nasopharyngeal carcinoma survivors. J Clin Microbiol 38: 2219-2216.

14. Xu L, Zhang H, Liu J, Chen X (2013) Investigation of the oral infections and manifestations seen in patients with advanced cancer. Pak J Med Sci 29: 1112-1115.

15. Johanna E, Margaretha J, Tanya DL, Toerien AS, Bedeker M (2012) Incidence, severity and management of cancer chemotherapy related oral mucositis in Eastern Cape and Western Cape. Health SA Gesondheid 17.

16. McGuire DB, Fulton JS, Park J, Brown CG, Correa ME, et al. (2013) Systematic review of basic oral care for the management of oral mucositis in cancer patients. Support Care Cancer 21:3165-3177.

17. Bey A, Ahmed SS, Hussain B, Devi S, Hashmi SH (2010) Prevention and management of antineoplastic therapy induced oral mucositis. Natl J Maxillofac Surg 1: 127-134.

18. Shih A, Miaskowski C, Dodd MJ, Stotts NA, MacPhail L (2002) A research review of the current treatments for radiation-induced oral mucositis in patients with head and neck cancer. Oncol Nurs Forum 29: 1063-1080.
19. Polit DF, Hunglar BP (1999) Nursing research: principals and methods. 6th Edn, Philadelphia: J. B. Lippincott Company

20. Suresh KS. Nursing research and statistics. 2nd Edn New Delhi: Elsevier P. 56-9, 70-1.

21. Wuketich S, Hienz SA, Marosi C (2012) Prevalence of clinically relevant oral mucositis in outpatients receiving myelosuppressive chemotherapy for solid tumors. Support Care Cancer 20: 175-183.

22. McCarthy GM, Awde JD, Ghandi H, Vincent M, Kocha WI (1998) Risk factors associated with mucositis in cancer patients receiving 5fluorouracil. Oral Oncol 34: 484-490.

23. Raber-Durlacher JE, Weijl NI, Abu Saris M, de Koning B, Zwinderman $\mathrm{AH}$, et al. (2000) Oral mucositis in patients treated with chemotherapy for solid tumors: a retrospective analysis of 150 cases. Support Care Cancer 8: 366-371

24. Pérez Camargo DA, De Nicola Delfín L, Namendys-Silva SA, Copca Mendoza ET, Hernández Méndez M, et al. (2013) [Nutritional status of patients with cancer of oral cavity]. Nutr Hosp 28: 1458-1462.

25. Rose-Ped AM, Bellm LA, Epstein JB, Trotti A, Gwede C, et al. (2002) Complications of radiation therapy for head and neck cancers. The patient's perspective. Cancer Nurs 25: 461-467.

26. Azher U, Shiggaon N (2013) Oral health status of children with acute lymphoblastic leukemia undergoing chemotherapy. Indian J Dent Res 24: 523.

27. Ogama N, Suzuki S (2012) Adverse effects and appetite suppression associated with particle beam therapy in patients with head and neck cancer. Jpn J Nurs Sci 9: 28-37.

28. Cheng KK (2007) Oral mucositis and quality of life of Hong Kong Chinese patients with cancer therapy. Eur J Oncol Nurs 11: 36-42.

29. Vera-Llonch M, Oster G, Hagiwara M, Sonis S (2006) Oral mucositis in patients undergoing radiation treatment for head and neck carcinoma. Cancer 106: 329-336.

30. Rao S, Dinkar C, Vaishnav LK, Rao P, Rai MP (2013) The Indian spice turmeric delays and mitigates radiation-induced oral mucositis in patients undergoing treatment for head and neck cancer: an investigational study. Integr Cancer Ther 13: 201-210.

31. Elad S, Meidan I, Sellam G, Simaan S, Zeevi I, et al. (2013) Topical curcumin for the prevention of oral mucositis in pediatric patients: case series. Altern Ther Health Med 19: 21-24.

32. Agarwal KA, Tripathi CD, Agarwal BB, Saluja S (2011) Efficacy of turmeric (curcumin) in pain and postoperative fatigue after laparoscopic cholecystectomy: a double-blind, randomized placebo-controlled study. Surg Endosc 25: 3805-3810.

33. Ryan JL, Heckler CE, Ling M, Katz A, Williams JP et al. (2013) Curcumin for radiation dermatitis: a randomized, double-blind, placebo-controlled clinical trial of thirty breast cancer patients. Radiat Res 180: 34-43.

34. Rao S, Dinkar C, Vaishnav LK, Rao P, Rai MP, et al. (2013) The Indian spice turmeric delays and mitigates radiation-induced oral mucositis in patients undergoing treatment for head and neck cancer: an investigational study. Integr Cancer Ther 13: 201-210.

35. Turhal NS, Erdal S, Karacay S (2000) Efficacy of treatment to relieve mucositis-induced discomfort. Support Care Cancer 8: 55-58.

36. Cho EA, Kim KH, Park JY (2010) Effects of frozen gauze with normal saline and ice on thirst and oral condition of laparoscopic cholecystectomy patients: pilot study. J Korean Acad Nurs 40: 714-723.

37. Griffin B, Cooper H, Horack C, Klyber M, Schimmelpfenning D (2007) Best-practice protocols: reducing harm from pressure ulcers. Nurs Manage 38: 29-69.

38. Yallapu MM, Jaggi M, Chauhan SC (2013) Curcumin nanomedicine: a road to cancer therapeutics. Curr Pharm Des 19: 1994-2010. 